4. The panel judge preparing the opinion will circulate a draft of his opinion among all the.circuit judges.

5. The litigant may petition all the circuit judges for an en banc hearing at the time the appeal is filed. He may also petition the panel for a rehearing en banc after the decision is given. ${ }^{32}$ The panel must consider the motion for a rehearing en banc apart from that for a rehearing by the original panel. ${ }^{33}$

A majority of the full court should have the opportunity to order an en banc session any time in order to avoid a decision which would not represent the view of the entire court. That provision would be complemented by the adoption of the Third Circuit's practice of circulating a draft of the panel's opinion, which seems best suited to acquaint all the judges with the issues in a case. While only a majority of all the judges should be able to grant petitions for rehearings en banc, these should be addressed to the original panel, any member of which might then bring the matter to the attention of the whole court if he so chooses. If no member of the panel believes that an en banc rehearing is warranted, the petition could be denied without reference to the whole court since the litigant does not have the right to address all the circuit judges after his case has been assigned to a panel. Each Court of Appeals would thus have the advantage of litigants' suggestions for the use of a procedure which is primarily intended for its own benefit without the administrative burden which consideration of each petition by the full Court would entail.

32 Considering the reasons for which en banc procedures should be granted, it may be argued that a litigant should be allowed to petition for a rehearing en banc only if the panel has departed from a precedent and has itself created a conflict, for he knows about a prior conflict or the importance of his case before the original hearing. On the other hand, for tactical reasons the litigant's attorney is hard put to decide whether or not he should suggest that his case is important enough for an en banc session.

The panel should have final disposition over a motion for rehearing and should be able to deny a petition for a rehearing en banc or to grant it subject to the approval of a majority of the circuit judges. If the litigant were given the right to petition all of the circuit judges after his case has been assigned to a panel, a new appellate court would be created between the three judge panel and the Supreme Court, a court which has no statutory existence. See page 450 supra.

${ }^{33}$ See note 28 supra. This would appear to be the mandate of the Supreme Court in the Western Pacific Railroad case, 345 U.S. 247, 262 (1953). It may be psychologically difficult, however, for the panel to consider the two questions separately. Hence, it would be wise to allow any member of the panel rather than a majority of the panel to recommend it to the other circuit judges.

\title{
TRUST APPORTIONMENT OF CORPORATE DISTRIBUTIONS FROM FIXED ASSETS
}

Rights of the life beneficiary and remainderman of a stock trust to corporate distributions have repeatedly presented difficult problems. ${ }^{1}$ The typical trouble-

1 Trusts, whose res consists of stock in wasting asset corporations or in trading corporations, such as those primarily engaged in the purchase and sale of real estate, are not discussed herein because as to such corporations, a different disposition, as between life beneficiary and 
some case occurs when the trust instrument does not specify clearly which of different types of corporate distributions are to be awarded to the life beneficiary, as when it provides that all or a portion of the estate of the settlor is to remain or be invested in stock, the life beneficiary to have in general terms the income, dividends, and profits for life, with remainder over. Although it is reasonably certain that in such a case the settlor intends the life beneficiary to have ordinary dividends from current income, it is not clear whether stock dividends as well as cash dividends are to be treated as income of the trust. His intention is unclear, too, as regards the distribution of extraordinary dividends from accumulated earnings and distributions from the proceeds of the sale of fixed assets.

In most American jurisdictions one of two sets of doctrines, ${ }^{2}$ the Pennsylvania or Massachusetts rule, will be applicable to a controversy concerning such an apportionment of dividends when the intent of the settlor cannot be ascertained. This comment will discuss the application of these rules to the special case in which the source of the distributions is a fixed asset.

\section{I}

The general Pennsylvania rule regarding corporate distributions is that the life beneficiary is entitled to all dividends, whether of stock or cash, based upon surplus earnings accumulated after the trust shares became subject to the life interest, ${ }^{3}$ and to ordinary dividends even though related to earnings accumulated before the trust shares became subject to the life interest. ${ }^{4}$ If the dividends

remainderman, is accorded to distributions. In regard to wasting asset corporations see 13 A.L.R. 1009 (1921); 56 A.L.R. 1316 (1928); and 81 A.L.R. 543 (1932). In regard to trading corporations, proceeds from the sale of assets would be the only source available for distribution to the life beneficiary. See 4 Bogert, Trusts and Trustees, c. 40, $\$ 855$ (1935).

2 For various rules for apportionment of corporate dividends see 4 Bogert, Trusts and Trustees, c. 40, 8843 (1935); 130 A.L.R. 492 (1941).

A majority of American jurisdictions follow the Massachusetts rule as formulated by case law or as expressed in the Uniform Principal and Income Act. See 130 A.L.R. 492 (1941); 94 U.L.A. (Pocket Supplement) 24 (1951). Since the Uniform Principal and Income Act does not apply to trusts created before the Act was adopted [Sec. 17, 9A U.L.A. 244 (1951)] the Pennsylvania rule is applicable to such trusts in those jurisdictions following it prior to adopting the Act. See In re Crawford's Estate, $362 \mathrm{~Pa} .458,67 \mathrm{~A} .2 \mathrm{~d} 124$ (1949), where a retroactive application of the Act was held unconstitutional.

3 Earp's Appeal, 28 Pa. 368 (1857); Appeal of Smith, 140 Pa. 344, 21 Atl. 438 (1891); 4 Bogert, Trusts and Trustees, c. 40, $\$ 848$ (1935); 130 A.L.R. 492 (1941). Pennsylvania has adopted the Uniform Principal and Income Act which purports to embody the Massachusetts Rule in regard to apportionment of corporate distributions between life beneficiary and remainderman. 20 Purdon's Pa. Statutes Ann. $\$ 3470.1$ et seq. (1947).

The life interest commences when the trustee purchases the shares if they were not part of the corpus when the trust was established. Baldwin v. Baldwin, 159 Md. 175, 150 Atl. 282
(1930).

${ }^{4}$ In re Opperman's Estate, 319 Pa. 455, 179 Atl. 729 (1935). The Pennsylvania rule is logically inconsistent in that apportionment of extraordinary dividends, in a proper case, is required, while the same disposition is not accorded to ordinary dividends. Bogert has suggested that ordinary dividends, those in harmony with the customary practices of the corporation, 
are extraordinary, and represent surplus earnings acquired both before and after the effectiveness of the life interest, an apportionment is required, ${ }^{5}$ the life beneficiary receiving only the latter. Except for the allocation of ordinary dividends the trustee is under a duty to preserve the "intact value" of the corpus, namely, the book value of the trust shares at the time they became subject to the life interest. ${ }^{6}$

Few cases have applied these general rules to the special case of distributions -attributable to proceeds of sales of fixed assets pursuant to either partial or total liquidation. Those that have indicate that in the case of partial liquidation-the sale of any fixed asset not a part of the winding up of the corporation - the proceeds are awarded to corpus if the asset was acquired before the trust shares became subject to the life interest. ${ }^{7}$ However, this rule may be unjust to the life tenant. Such a distribution, as a matter of accounting, decreases the surplus account of the corporation by the amount of the distribution. If there are any surplus earnings which have accumulated after the trust shares became subject to the life interest, the decrease will absorb them. Thus the life tenant may be deprived of a distribution to which he is entitled, while the remainderman is unduly benefited. This is the case because the trustee, in fulfilling his obligation to maintain the "intact value" of the corpus, may not award to the life beneficiary distributions which represent surplus earnings accumulated before his interest in the particular trust shares commenced, ${ }^{8}$ except for ordinary dividends.

are not apportioned because the relatively small amount in issue does not justify the expense that would be involved in obtaining the data necessary for an apportionment. Other reasons for not apportioning ordinary dividends are also given in 4 Bogert, Trusts and Trustees, c. 40, $\$ 844$ (1935).

In re Stokes' Estate, 240 Pa. 277, 87 Atl. 971 (1913).

- For a statement of the rule see In re Nirdlinger's Estate, 327 Pa. 160, 193 Atl. 33 (1937), where proceeds were from a sale of shares by the trustee rather than a corporate distribution. Certain trust shares whose intact value was $\$ 20,000$ were sold for $\$ 170,000$. The lower court awarded the entire proceeds to the remainderman. Judgment was affirmed without prejudice to the life beneficiary to reopen the judgment of the lower court and prove that $\$ 40,000$ of the proceeds were due to earnings which had accumulated after the trust shares became subject to the life interest. Cf. In re McKeown's Istate, $263 \mathrm{~Pa}$. 78, $106 \mathrm{Atl}$. 189 (1919). Contra: In re Traung's Estate, 30 Cal. 2d 811, 185 P. 2d 801 (1947).

7 In re Graham's Estate, 198 Pa. 216, 47 Atl. 1108 (1901) (proceeds from condemnation proceedings); Vinton's Appeal, $99 \mathrm{~Pa} .434$ (1882) (proceeds from franchise of gas company); In re Eilert's Estate, 131 Cal. App. 409, 21 P. 2d 630 (1933) (trustee was directed to withhold from subsequent distributions of income to which the life beneficiary would normally be entitled an amount sufficient to reimburse corpus for distributions from the sale of real estate, which previously had been erroneously awarded to the life beneficiary); Miller v. Payne, 150 Wis. 354, 136 N.W. 811 (1912).

Under the general Pennsylvania rule it would seem that distributions from the proceeds of the sale of those assets acquired from earnings accumulated after the trust shares became subject to the life interest would be awarded to the life beneficiary to the extent that the distribution represented reinvested "earnings" if such an apportionment would noi reduce the intact value of the corpus.

In jurisdictions following the Pennsylvania rule, no case could be found which held that in such a situation the trustee could thereafter maintain the intact value of the trust shares 
For example, if the distributing corporation purchases a building with surplus earnings accumulated after the trust shares became subject to the life interest, and at the same time sells and distributes the proceeds from a building acquired before the life interest attached to the particular trust shares, the corpus receives the entire distribution. However, if the corporation, instead, had retained the older building and distributed the surplus earnings, the amount in question would go to the life beneficiary. It would appear that so long as the intact value of the corpus is maintained, the immediate source of a corporate distributionwhether from the sale of a fixed asset acquired before the life interest in the trust shares came into being, or cash representing surplus earnings accumulated after the life interest arose-should not be controlling as regards the rights of life beneficiary and remainderman.

However, those cases which deal with this problem do not consider the loss which may occur to the life beneficiary. In In re Graham's Estate, ${ }^{9}$ where proceeds received fron condemnation proceedings were awarded to corpus, although the court said that no portion of the proceeds represented surplus earnings, it did not indicate whether any earnings had accumulated after the trust shares became subject to the life interest. In Miller v. Payne $e^{10}$ proceeds from the sale of real estate were awarded to corpus. The life beneficiary was denied an amount of the proceeds equivalent to earnings accumulated after the trust shares became subject to the life interest. The court emphasized that the corporate resolution authorizing the distribution stated that it was from the proceeds of real estate rather than earnings.

In case of total liquidation of the corporation the proceeds of the sale of fixed assets are awarded to corpus, except that the life beneficiary receives any portion representing surplus earnings which accumulated after the trust shares

in the distributing corporation at a lower amount, namely, the original intact value less the book value of the asset when the particular trust shares became subject to the life interest. This treatment, at first glance, might seem practicable since the asset involved was taken into consideration in computing the original intact value of the trust shares.

For example, suppose the book value of each share when the trust was created was $\$ 2.00$, the corporation having assets worth $\$ 200,000$, surplus of $\$ 100,000$ and capital stock of $\$ 100,000$ par value with 100,000 shares outstanding. Immediately before the distribution, suppose that the book value of each share was $\$ 2.50$ and that the increase was due to $\$ 50,000$ of surplus earnings accumulated since the effectiveness of the life interest. If a fixed asset acquired before the life interest is sold for its book value of $\$ 50,000$, and the proceeds are distributed, the book value of each share is once more $\$ 2.00$. Since corpus rather than the life beneficiary receives the trust's share of the distribution and the intact value of the stock is the same as it was when the trust was created, it might seem practicable thereafter to maintain the intact value of the corpus at $\$ 1.50$ per share. This would permit the life beneficiary to be reimbursed subsequently by receiving either surplus earnings accumulated before the effectiveness of his interest or gains from the sale of fixed assets. However, assuming that such administration by the trustee is permissible, it would seem unnecessary to postpone the life beneficiary's receipt of a sum of money which he should have been awarded in the first instance by permitting him to recover it subsequently from something to which he normally does not have a claim.

9 198 Pa. 216, 47 Atl. 1108 (1901).

I0 150 Wis. 354,136 N.W. 811 (1912). 
became subject to the life estate which were reinvested in the corporation in the form of fixed assets. ${ }^{11}$ In these cases there seems to be no controversy between the life beneficiary and remainderman regarding the source of the proceeds comparable to that which arises in partial liquidations. The reason for this may be that in the cases decided the corporation has realized and the trust has received an amount sufficient to cover both the intact value of the corpus and accumulated earnings due the life tenant.

Where gain has been realized from the sale of a fixed asset, it is awarded to corpus when distributed. This is the case in both partial ${ }^{12}$ and total liquidations, ${ }^{13}$ probably regardless of whether the asset sold was acquired before or after the trust shares became subject to the life interest. Although it might be argued that the life beneficiary should be entitled to any gain realized after the trust shares became subject to the life estate, by analogy with other corporate earnings, the courts have reasoned that such gain should go to corpus because it is realized in a transaction which is outside the scope of the usual business activity of the corporation. This rationale would seem equally applicable to assets acquired after the life interest commenced, though no cases involving such a transaction have been found.

Although the corpus is awarded gains realized from the sale of fixed assets on liquidation, the life beneficiary may bear the brunt of losses occurring in such cases. In instances of total liquidation the life beneficiary is given proceeds representing surplus earnings accumulated after the trust shares became subject to the life interest only if the trust receives an amount greater than the intact value of the corpus. ${ }^{14}$ Thus, for example, where fixed assets depreciate in value the life tenant bears the loss.

II In re Daily's Estate, $323 \mathrm{~Pa} .42,186$ Atl. 754 (1936). Although the balance sheet of the distributing corporation, a match company, was not given in the opinion, the book value of the trust shares had approximately doubled and it would seem more probable than not that some of this increase was retained in the form of fixed assets. Cf. In re Schaefer's Estate, 155 Misc. 850, 280 N.Y.Supp. 630 (Surr. Ct., 1935). On liquidation of a realty corporation, proceeds from cight parcels of land acquired from earnings which had accumulated after the trust shares became subject to the life interest were awarded to the life beneficiary. However, that particular apportionment was not in issue. See language in In re Chauncey's Estate, $303 \mathrm{~Pa}$., 441, 448,154 Atl. 814, 816 (1931), where, however, the distribution was not made pursuant to liquidation. The court said: "Where earnings are produced from the entire capital or part of it and invested in capital assets, any stock dividends declared thereon will be treated as income and will be divided between the life tenant and the remainderman so as to preserve the intact value of the stock."

${ }^{12}$ McCoy v. McCloskey, 94 N.J. Eq. 60, 117 Atl. 473 (1922), rejected the life beneficiary's claim that proceeds in excess of the book value of the assets were income within the meaning of the trust instrument, which, however, directed that proceeds realized from liquidation or dissolution were to be reinvested.

${ }^{13}$ In re Eilert's Estate, 131 Cal. App. 409, 21 P. 2d 630 (1933); Ex parte Humbird, 114 Md. 627, 80 Atl. 209 (1911).

14 Re Sternbergh's Estate, 339 Pa. 342, 10 A. 2d 376 (1939). Compare Estate of Gerlach, 177 Wis. 251, 188 N.W. 94 (1922). 
Similarly, in the case of partial liquidation, the life tenant may bear losses resulting from the depreciation of fixed assets, ${ }^{15}$ though corpus is awarded gains in such a case. The loss would typically be charged against a surplus account of the distributing corporation and thereby absorb surplus earnings, if any, to which the life tenant would otherwise be entitled.

\section{II}

The general Massachusetts rule is that dividends in cash $^{16}$ and stock of a corporation other than the declaring one ${ }^{17}$ are awarded to the life beneficiary. However, the corpus is awarded dividends pursuant to total liquidation of the declaring corporation ${ }^{18}$ and dividends in stock of the declaring corporation. ${ }^{19}$

Those few cases that have dealt with the problem of distribution of proceeds from the sale of fixed assets when the sale is not pursuant to total liquidation indicate that the life beneficiary will receive dividends in cash, or stock of a corporation other than the declaring one, so long as the "capital" of the distribut-

${ }^{15}$ In re Dickinson's Estate, $285 \mathrm{~Pa} .449$, 132 Atl. 352 (1926), would seem applicable although the sale of a fixed asset was not involved. "Extraordinary" losses (losses incurred when a distributing insurance company had, prior to the distribution in issue, paid claims resulting from the San Francisco fire) to the extent that they absorbed earnings accumulated after the trust shares became subject to the life interest were borne by the life beneficiary. When the trust was established, the book value of each share was $\$ 142.61$. After the "extraordinary" loss, which was partially absorbed by surplus which accumulated during the life interest, the book value per share was $\$ 71.09$. The company thereafter issued stock so that the book value the trustee was required to maintain was raised from $\$ 71.09$ per share to $\$ 162.50$. A stock dividend of $100 \%$ was issued and the life beneficiary received that portion in excess of the intact value per share, $\$ 162.50$. Kephart, J. dissented because the corpus was not restored to the extent that the loss had been absorbed by earnings which had accumulated before the trust was established.

In regard to the position expressed in the dissenting opinion see In re Lueders' Estate, $337 \mathrm{~Pa} .155,10 \mathrm{~A} .2 \mathrm{~d} 415$ (1940), where it was held that operating losses incurred by the distributing corporation during the depression, which had reduced the intact value of the particular trust shares, were "ordinary" operating losses and consequently the life beneficiary was entitled to no portion of any extraordinary dividends until restoration of the intact value of the trust shares at the time they first became subject to the life interest.

Bourne v. Bourne, 240 N.Y. 172, 148 N.E. 180 (1925), is contra to Dickinson's Estate in regard to restoration of corpus after extraordinary loss reduces its intact value. In the New York case, the distributing corporation in 1919 had incurred large losses on its Russian investments; and it was held that until the intact value of the trust shares was restored, the life beneficiary could receive only "ordinary" dividends. New York has partially adopted the Massachusetts rule in regard to allocation of corporate distributions between the life beneficiary and corpus by enacting a statute which provides that stock dividends of the declaring corporation are to be regarded as trust principal unless otherwise provided in the trust instrument. N.Y. Personal Property Law $\$ 17$ a (1926).

${ }^{16}$ Talbot v. Milliken, 221 Mass. 367, 108 N.E. 1060 (1915). If the trustee has the option to receive the distribution in cash or stock of the declaring corporation, the distribution is deemed a cash dividend. Davis v. Jackson, 152 Mass. 58, 25 N.E. 21 (1890).

${ }^{17}$ Gray v. Hemenway, 268 Mass. 515, 168 N.E. 102 (1929). See 130 A.L.R. 492 (1941).

18 Gifford v. Thompson, 115 Mass. 478 (1874). See 130 A.L.R. 492 (1941).

${ }^{19}$ Minot v. Paine, 99 Mass. 101, 96 Am. Dec. 705 (1868). See 130 A.L.R. 492 (1941). 
ing corporation is not impaired, ${ }^{20}$ i.e., so long as the distributing corporation maintains assets equal in amount to liabilities plus capital stock..$^{21}$

In Gray v. Hemenway 22 the dividend was in stock of a corporation other than the declaring one. The stock had been received in exchange for bonds which had been issued by a third corporation to the declaring corporation as payment for coal properties purchased from the declaring corporation. The dividend, while traceable to the sale of a fixed asset, was awarded to the life beneficiary. In .Smith v. Dana ${ }^{23}$ the life beneficiary received the proceeds from the sale of a gas plant which the distributing corporation had acquired before the trust was established: Although Connecticut follows the Massachusetts rule, ${ }^{24}$ the court pointed out that the surplus of the corporation at the time of the distribution was three times as large as it had been when the trust was established.

Under the Massachusetts rule it would seem that the life beneficiary is entitled to distributions which represent only the gain realized from the sale of a fixed asset so long as capital is not impaired. In those cases where the life beneficiary has received the entire distribution of proceeds from the sale of fixed assets, no distinction has been made between the book value of the asset and gain, if any, realized from the sale. ${ }^{25}$

\section{III}

Under the Pennsylvania rule the intact value of the corpus is preserved for the benefit of both the life beneficiary and the remainderman. The remainderman is entitled not only to the gains ${ }^{26}$ realized from the sale of fixed assets, but

${ }^{20}$ Gray v. Hemenway, 268 Mass. 515, 168 N.E. 102 (1929); Smith v. Dana, 77 Conn. 543, 60 Atl. 117 (1905); Lloyd v. Lloyd, 341 Ill. 461, 173 N.E. 491 (1930). Accord: Davis v. Jackson, 152 Mass. 58, 25 N.E. 21 (1890); Whiting v. Hagey, 366 IIl. 86, 7 N.E. $2 d 885$ (1937) (liquidation of wholly owned subsidiary which was established largely from surplus assets of the parent corporation). Contra: Walker v. Walker, 68 N.H. 407, 39 Atl. 432 (1895).

21 Gray v. Hemenway, 268 Mass. 515, 168 N.E. 102 (1929).

2 Ibid.

2377 Conn. 543, 60 Atl. 117 (1905).

24 Spooner v. Phillips, 62 Conn. 62, 24 At1. 524 (1892).

${ }^{25}$ In the cases cited in footnote 20, Gray v. Hemenway was the only one in which it clearly appeared that gain was involved.

${ }^{25}$ But see In re Mathews' Estate, 210 Wis. 109, 245 N.W. 122 (1932), concerning a distribution under the Pennsylvania rule from a reserve for depreciation account. On total liquidation, a building of the distributing corporation was sold for $\$ 1,300,000$, its original cost having been $\$ 240,000$. The reserve for depreciation account, as a matter of corporate accounting, was apparently transferred to a surplus or retained income account. A distribution based upon the surplus account increased in this manner was awarded to the life beneficiary; or in other words, is between life beneficiary and corpus, the amount in the reserve for depreciation account apparently was not subtracted from the cost of the asset in computing the gain realized from the sale of the building, which under the Pennsylvania rule is awarded to corpus.

Gains and losses from the sale of assets and depreciation expense, as affects the rights of life beneficiary and corpus, are treated differently if the trust res consists of unincorporated fixed assets than if it consists of stock. In regard to unincorporated fixed assets, corpus usually is awarded the proceeds from sales, receiving gains as well as bearing losses, where the trustee has a privilege to sell. See 102 A.L.R. 970 (1936); 4 Bogert, Trusts and Trustees, c. 39, 8823 
also to the amount at which the asset was valued on the books of the distributing corporation when the life interest became effective if the asset was not acquired with surplus earnings which accumulated during the life interest. Distribution of the latter to corpus may cause a bookkeeping loss to the life beneficiary. Furthermore, losses realized from the sale of fixed assets first absorb surplus earnings to which the life beneficiary is normally entitled before any part is charged against surplus earnings representing the intact value of the corpus.

The Pennsylvania rule, although more equitable in theory than the Massachusetts rule, presents formidable problems of administration for the trustee. The intact value of the corpus is difficult to compute unless the trust is established at a date on which each corporation in which the trust holds stock has issued a financial report. Also, if an ideal adjustment is to be effected between life beneficiary and remainderman in regard to distributions from the proceeds of the sale of fixed assets, the trustee must know to what extent the surplus account of the distributing corporation is attributable to gains from the sale of fixed assets after the trust has been established. Where the surplus account represents both gains from the sale of fixed assets as well as accumulated earnings to which the life beneficiary is entitled, the trustee, in most instances, will not know which segment of the surplus account has been charged for the distribution. Since in most cases this sort of detailed information is not available it has been said that the Pennsylvania rule is impractical as regards administration of stock trusts. ${ }^{27}$

Under the Massachusetts rule, as long as "capital" is not impaired, the life beneficiary is entitled to dividends from the proceeds of a partial liquidation of fixed assets if distributed in the form of cash or stock of another corporation. Such a disposition is not treated differently than the apportionment of extraordinary cash dividends. In addition, it would seem that gains or losses from the sale of fixed assets would be credited or charged to the surplus account of the distributing corporation and, as such, would be a basis upon which distributions to the life beneficiary might be affected, depending on the form of the distribution.

The Massachusetts rule is easier to apply. The trustee need not ascertain the amount of earnings which have accumulated since the establishment of the trust. Generally stock dividends are awarded to corpus and cash dividends to the life beneficiary. Dividends pursuant to total liquidation are awarded to corpus. Therefore, it does not seem unfair to award to the life beneficiary dividends from

(1935). Furthermore, the general rule is that depreciation may not be deducted from gross rents in computing net rents to be awarded to the life beneficiary unless the trust instrument authorizes such a deduction. 3 Bogert, Trusts and Trustees, c. 29, $\$ 600$ (1935). However, depreciation is an expense which a corporation takes into account in computing net income from which dividends are usually declared.

27 Commissioner's Prefatory note to Uniform Principal and Income Act, 9A U.L.A. 225, 226 (1951). 
partial liquidations of fixed assets so long as "capital" is not impaired, and the distribution is.in the form of cash or the stock of another corporation. However, there are too few cases to establish this proposition as law.

The Uniform Principal and Income Act purports to adopt the Massachusetts rule as regards disposition of cash and stock dividends. ${ }^{28}$ It is uncertain which part of the Act is to govern in the case of a distribution of assets which does not involve a winding up of the business, ${ }^{29}$ but there are three ways in which the Act - might be read as providing for this situation. Section 5 (3), relating to the liquidation of assets, reads:

Where the assets of a corporation are liquidated, amounts paid upon corporate shares as cash dividends declared before such liquidation occurred or as arrears of preferred or guaranteed dividends shall be deemed income; all other amounts paid upon corporate shares on disbursement of the corporate assets to the stockholders whenever made, which are designated by the corporation as a return of capital or division of corporate property shall be deemed principal. All disbursements of corporate assets to the stockholders, whenever made, which are designated by the corporation as a return of capital or division of corporate property shall be deemed principal.

The first sentence of this Section does not seem to provide for different treatment of disbursements from assets when made pursuant to partial liquidation than when made pursuant to total liquidation. If it is assumed that the two sentences of Section 5 (3) are coextensive and apply to both partial and total liquidations, the Section is a departure from the Massachusetts rule as to distributions from the proceeds of partial liquidations: ${ }^{30}$ in the Massachusetts cases it does not appear that the time of the sale of the assets in relation to the time of the declaring of the dividend was deemed important.

A second possible interpretation is that the first sentence refers only to total liquidations. The language there is narrower than that of the second sentence, where the reference is to "all disbursements of assets to stockholders, whenever made...." Assuming that the latter sentence does cover partial and total liquidations, it would seem to be a departure from the tenor of certain cases decided under the Massachusetts rule ${ }^{31}$ in that it indicates that the designation of

${ }^{28} \mathrm{Ibid}$. The Act applies only when the settlor has not provided for matters covered therein. \$2-Application of the Act-Powers of Settlor, 9A U.L.A. 229 (1951).

${ }^{29}$ The Restatement of Trusts, which is clearer on this point, reads: "upon the total or partial liquidation of the corporation during the period, amounts paid as cash dividends declared before such liquidation occurred or as arrears of preferred or guaranteed dividends are income; all other amounts paid upon corporate shares on disbursement of the corporate assets to the shareholders are principal." Rest., Trusts \$236(e) (Supp., 1949).

${ }^{30}$ See cases cited in note 20 supra. .

${ }^{31}$ See Heard v. Eldredge, 109 Mass. 258 (1872), where the court rejected the contention of the life beneficiary that the intention of the directors of the distributing corporation should control in regard to whether the distribution represented "capital" or "income." The source of 
the distribution by the distributing corporation is to be controlling in regard to the rights of the life beneficiary and the remainderman.

Another possibility is that Section 5 (3) does not fully cover partial liquidations, ${ }^{32}$ but fully covers total liquidations. If this is the case, allocation of distributions based upon partial liquidations would seem to be determined by Section 5 (1) ${ }^{33}$ of the Act, which supposedly adopts the Massachusetts rule in regard to allocation of ordinary and extraordinary dividends. However, the second sentence of Section 5 (3) seems to modify Section 5 (1), because payment of dividends by the declaring corporation in cash or in stock of another corporation involves a disbursement of assets by the declaring corporation. However, as indicated above, to permit a particular designation by the distributing corporation to control the apportionment between life beneficiary and remainderman is contrary to the Massachusetts rule concerning apportionment of ordinary and extraordinary dividends.

From the preceding analysis it appears that the Massachusetts rule, as formulated by the cases, and the Uniform Principal and Income Act provide for

the distribution was from the proceeds of land taken by eminent domain. In Gray v. Hemenway, 268 Mass. 515, 168 N.E. 102 (1929), the court said that although the substance rather than the form controls in determining the nature of a dividend, a court will not ordinarily examine the accounts of the distributing corporation for the purpose of ascertaining the source of the distribution. However, in that case the source of the distribution was ascertained, and in addition, "capital" was not impaired.

32 Perhaps "return of capital" in the second sentence of Section 5 (3) also pcrtains to situations involving partial redemption by a corporation of its stock. Some corporations issue stock dividends based upon accumulated earnings and subsequently redeem the issuc in cash. In such a situation, if the Board of Tax Appeals find that the transaction was a plan to distribute the accumulated earnings of the company, the stockholder for tax purposes is dcemed to have received income. Compare Randolph v. Commissioner, 76 F. 2 d 472 (C.A. 8th, 1935), with Commissioner v. Champion, 78 F. 2d 513 (C.A. 6th, 1935). But according to the second sentence of Section 5 (3), as regards the rights of the life tenant and the remainderman, he would be deemed to have received principal. In situations where the stock dividend was part of a plan to distribute the surplus earnings of the corporation, perhaps the courts, following the Uniform Act, might look behind the form of the corporate distribution and regard such distributions as cash dividends. On the other hand, if the sccond sentence of Section 5 (3) wcre applicable, a different result might be reached.

In jurisdictions following the Massachusetts cases which have not adopted the Uniform Act, the courts again might look behind the form of the transaction, awarding the proceeds of the sale to the life tenant, or on the other hand, they might regard the transaction as a partial sale of corpus.

This particular problem does not seem to have been litigated either under the Act or in those states following the Massachusetts rule.

${ }_{33}$ "All dividends on shares of a corporation forming part of the principal which are payable in the shares of the corporation shall be deemed principal. Subject lo the provisions of this section, all dividends payable otherwise than in the shares of the corporation itself, including ordinary and extraordinary dividends... shall be deemed income. Where the trustee shall have the option of receiving a dividend either in cash or in the shares of the declaring corporation, it shall be considered as a cash dividend and deemed income, irrespective of the choice made by the trustee." (Italics ad.led.) 9A U.L.A. 233 (1951). 
different treatment of corporate distributions from fixed assets. The Massachusetts rule awards cash dividends and dividends in stock of a corporation other than the declaring one to the life beneficiary as long as the distributing corporation has surplus available. The Uniform Principal and Income Act awards to corpus all distributions, i.e., disbursements of corporate assets, which the distributing corporation designates as a return of capital or division of corporate property.

Since fixed assets, for almost all purposes, are thought of as "capital," it is not surprising that distributions traceable to their sale tend to be treated as returns of capital and awarded to corpus rather than as distributions of income and awarded to the life beneficiary. However, since a corporation in the course of its business activities regularly transforms its assets by recovering depreciation expense in the form of liquid assets, the source of a distribution should not determine its apportionment. Instead, attention should be directed to the state of the surplus account of the distributing corporation. Does it, immediately before the distribution, reflect profits which, if distributed, would be awarded to the life beneficiary pursuant to the various apportionment rules? Will all or part of the distribution, as a matter of corporate accounting, be charged against this increase, so that the amount involved is no longer available for ordinary distribution? If the answer to both of these questions is in the affirmative, trustees should be allowed to award the distribution, whatever its source, to the life beneficiary. Such an approach to the problem gives recognition to the accounting concept of income and would facilitate a more equitable allocation between the life beneficiary and corpus.

\section{TAX EFFECTS OF ABSENCE OF MARKET VALUE ON EMPLOYEE BARGAIN PURCHASES-THE MARSHALL PLAN}

Corporations have often attempted to compensate employees by selling the corporation's securities to them at less than the market value $e^{1}$ so that the benefits are taxed at bargain capital gain rates. ${ }^{2}$ Where the market value at the time -of sale is ascertainable, courts have defeated such schemes by holding the excess of market over cost to be taxable as ordinary income to the employee. ${ }^{3}$ The re-

1 E.g.: Commissioner v. Smith, 324 U.S. 177 (1945); Wanda V. Van Dusen, 8 T.C. 388 (1947), aff'd 166 F. 2d 647 (C.A. 9th, 1948). Stock given to an employee as a bonus involves the same problems: Mason v. Commissioner, 125 F. 2d 540 (C.A. 6th, 1942);-O.D. 570, 1920 Cum. Bull. 144.

2 Int. Rev. Code $\S 117,26$ U.S.C.A. $\$ 117$ (1948). Consult Brodskey, Planning Business Transactions to Produce Capital Gain, N.Y.U. Seventh Ann. Inst. on Fed. Tax 302, 309 (1949).

2.Authorities cited note 1 supra. But cf. Omaha Nat'l Bank v. Commissioner, 75 F. 2d 434 (C.A. 8th, 1935). 